\title{
Faktor Risiko Diare Persisten pada Pasien yang Dirawat di Departemen IImu Kesehatan Anak RS Dr. Cipto Mangunkusumo Jakarta
}

\author{
IGN Sanjaya Putra, Agus Firmansyah, * Badriul Hegar, * Aswitha D Boediarso, * Muzal \\ Kadim, * Fatima Safira Alatas * \\ Departemen Ilmu Kesehatan Anak Fakultas Kedokteran Universitas Udayana RS Sanglah, Denpasar \\ * Departemen Ilmu Kesehatan Anak FKUI RS Cipto Mangunkusumo Jakarta
}

\begin{abstract}
Latar belakang. Program pengobatan rehidrasi oral telah berhasil mengontrol kematian akibat diare akut. Sekitar 3\%-20\% kasus diare akut pada anak akan berkembang menjadi diare persisten. Kematian akibat diare persisten cukup tinggi $\pm 65 \%$ dari seluruh kematian akibat diare.

Tujuan. Menentukan faktor risiko terjadinya diare persisten dan mengukur besar pengaruh tiap faktor risiko tersebut terhadap terjadinya diare persisten pada anak yang dirawat di ruang rawat inap bagian anak RS Dr. Cipto Mangukusumo Jakarta.

Metode. Rancang penelitian retrospektif, kasus-kontrol. Data penelitian diperoleh dari catatan medik pasien, semua pasien (54 pasien) diare persisten yang dirawat mulai 1 Januari 2004-30 Juni 2007 yang memenuhi kriteria inklusi dipilih sebagai kasus dan 108 pasien diare akut dipilih secara consecutive sampling sebagai kontrol.

Hasil. Pada analisis univariat didapatkan perbedaan bermakna antara 54 pasien dengan diare persisten (kasus) dan 108 pasien dengan diare akut (kontrol) dalam hubungan melanjutnya diare akut menjadi diare persisten pada faktor risiko: pemberian antibiotik ( $p=0,042, \mathrm{RO}: 1,984, \mathrm{IK}: 0,021-3,854)$, anemia $(p=0,005$, RO :2,568, IK: 1,313-5,024) dan malnutrisi ( $p=0,001$, RO : 10,974, IK :3,442-34,814). Pada regresi logistik multivariat, dua faktor risiko memperlihatkan hubungan yang bermakna yaitu anemia $(p=0,025$, RO :2,374, IK : 1,117-5,047) dan malnutrisi ( $p=0,001$, RO : 12,621, IK :3,580-44,814).

Kesimpulan. Anemia dan malnutrisi pada diare akut merupakan faktor risiko untuk melanjutnya diare akut menjadi diare persisten. (Sari Pediatri 2008;10(1):42-46).
\end{abstract}

Kata kunci: faktor risiko, anemia, malnutrisi, diare persisten

Alamat Korespondensi:

Dr. Badriul Hegar, Sp.A.(K) Divisi Gastroenterologi. Departemen Ilmu Kesehatan Anak FKUI-RSCM. Jl. Salemba no. 6, Jakarta 10430.

Telepon: 021-3915665. Fax.021-390 7743. 
$\mathrm{P}$ rogram rehidrasi oral pada diare akut telah berhasil meurunkan angka kematian akibat diare. ${ }^{1,2}$ Sekitar 3-20\% kasus diare akut pada anak akan berkembang menjadi diare persisten, ${ }^{1,3}$ dengan kematian $\pm 65 \%$ dari keseluruhan kematian karena diare. ${ }^{1}$

Dengan demikian pengenalan faktor risiko, pencegahan dan penanganan diare persisten merupakan hal yang sangat penting bagi dokter anak, untuk mencegah komplikasi atau bahkan kematian akibat dari diare persisten. Sejumlah faktor risiko dihubungkan dengan terjadinya diare persisten antara lain adalah: umur $<12$ bulan, ${ }^{3-5}$ berat badan lahir rendah, ${ }^{3-5,6,7}$ manultrisi, ${ }^{3}$ defisiensi vitamin $\mathrm{A},{ }^{3}$ defisiensi cell mediated immune, ${ }^{3,4}$ pemberian obat antidiare, pemberian antibiotika, ${ }^{3-8}$ anemia defisiensi besi ${ }^{6}$ riwayat diare berulang, ${ }^{3,5,6}$ kuman atau parasit sebagai penyebab, ${ }^{7}$ pemberian susu hewan, ${ }^{3-5,8}$ umur pendidikan dan pengalaman ibu, ${ }^{3,4,6}$ adanya penyakit penyerta. ${ }^{7}$ Pengalaman serta penanganan dini dan tepat pada diare persisten sangat diperlukan termasuk mengetahui faktor-faktor risiko berlanjutnya diare akut yang berkembang menjadi diare persisten.

\section{Metode}

Penelitian dengan desain kasus-kontrol, retrospektif, mengambil data dari catatan medik pasien yang rawat inap di bangsal Departmen Ilmu Kesehatan Anak Rumah Sakit Dr Cipto Mangunkusumo Jakarta mulai 1 Januari 2004- 30 Juni 2007. Kasus adalah semua pasien diare persisten yang memenuhi kriteria inklusi, sedangkan kontrol adalah pasien diare akut yang berumur 1 bulan-60 bulan pada periode yang sama dipilih secara consecutive sampling. Kriteria inklusi

Tabel 1. Sebaran faktor risiko dan kekuatan pengaruh masing-masing terhadap terjadinya diare persisten

\begin{tabular}{|c|c|c|c|c|c|}
\hline Faktor risiko & Kasus n (\%) & Kontrol n (\%) & Rasio Odds & CI 95\% & $p$ \\
\hline \multicolumn{6}{|l|}{ Umur (bulan) } \\
\hline$<12$ & $32(59,2)$ & $50(46,3)$ & 1,687 & $0,871-3,270$ & 0,120 \\
\hline 12 & $22(40,8)$ & $58(43,7)$ & & & \\
\hline \multicolumn{6}{|l|}{ Status gizi } \\
\hline$<70 \%$ & $16(29,6)$ & $4(3,7)$ & 10,974 & $3,442-34,814$ & 0,001 \\
\hline $70 \%$ & $38(70,3)$ & $104(96,3)$ & & & \\
\hline \multicolumn{6}{|c|}{ Pemberian antibiotik } \\
\hline Ya & $28(51,8)$ & $38(35,2)$ & 1,984 & $0,021-3,854$ & 0,042 \\
\hline Tidak & $26(48,2)$ & $70(64,8)$ & & & \\
\hline \multicolumn{6}{|c|}{ Pemberian antidiare } \\
\hline Ya & $7(12,9)$ & $13(12,0)$ & 1,088 & $0,407-2,909$ & 0,866 \\
\hline Tidak & $47(87,1)$ & $95(88,0)$ & & & \\
\hline \multicolumn{6}{|l|}{ Pemberian ASI } \\
\hline Ya & $27(50,0)$ & $48(44,4)$ & 1,250 & $0,650-2,406$ & 0,504 \\
\hline Tidak & $27(50,0)$ & $60(55,6)$ & & & \\
\hline \multicolumn{6}{|c|}{ Pemberian susu formula } \\
\hline $\mathrm{Ya}$ & $35(64,8)$ & $60(55,6)$ & 1,474 & $0,750-2,895$ & 0,259 \\
\hline Tidak & $19(35,2)$ & $48(44,4)$ & & & \\
\hline \multicolumn{6}{|l|}{ Berat badan lahir } \\
\hline BBLR & $6(11,1)$ & $14(12,9)$ & 0,839 & $0,303-2,322$ & 0,736 \\
\hline BBLC & $48(88,9)$ & $94(87,1)$ & & & \\
\hline \multicolumn{6}{|l|}{ Anemia } \\
\hline Ada & $33(61,1)$ & $41(37,9)$ & 2,568 & $1,313-5,024$ & 0,005 \\
\hline Tidak & $21(38,9)$ & $67(62,1)$ & & & \\
\hline \multicolumn{6}{|l|}{ Penyakit penyerta } \\
\hline Ada & $7(12,9)$ & $6(5,5)$ & 2,532 & $0,807-7,947$ & 0,102 \\
\hline Tidak & $47(87,1)$ & $102(94,5)$ & & & \\
\hline
\end{tabular}


diare persisten, yang berumur 1-60 bulan dan kriteria eksklusi diare persisten dengan IBD (inflammatory bowel disease), diare persisten dengan AIDS, dan diare persisten dengan data yang tidak lengkap.

Data yang terkumpul diuji dengan statistical product and service solution (SPSS) 13,5 dengan menggunakan interval kepercayaan (IK) 95\% dan dicari odds ratio (RO) masing-masing untuk tiap faktor risiko. Untuk data nominal dikotom dipakai uji chi square $\left(\mathrm{X}^{2}\right)$ atau Fisher, sedangkan untuk data numerik diuji t. Selanjutnya dilakukan uji multivariat regresi logistik untuk mencari faktor risiko yang paling berpengaruh terhadap diare persisten.

\section{Hasil}

Selama periode penelitian dari 1 Januari 2004-30 Juni 2007 didapat 62 pasien diare persisten. Delapan pasien dieksklusi dengan rincian, 3 pasien diare persisten dengan AIDS, 1 pasien diare persisten dengan IBD (inflammatory bowel disease) dan 4 pasien mempunyai data yang tidak lengkap, sedangkan pasien dengan diare akut pada periode yang sama dijumpai 932 pasien. Didapatkan laki-laki $26(48 \%)$ pasien dan perempuan $28(51,8 \%)$ pasien, sedangkan untuk kelompok kontrol didapatkan hasil laki-laki 60 (55,5\%) pasien dan perempuan $48(45,5 \%)$ pasien. Umur pada kasus rata-rata $(12,4 \pm 10,9)$ bulan dan pada kelompok kontrol $(14,5 \pm 11,4)$ bulan.

Pada Tabel 1 tertera sebaran faktor-faktor risiko berkembangnya diare akut menjadi diare persisten pada 54 kasus dan pada 108 kasus kontrol. Dari faktor risiko yang diuji dengan analisis univariat ternyata faktor risiko yang ada hubungan dengan berkembangnya diare akut menjadi diare persisten berturut-turut yaitu status gizi $<70 \%$, adanya anemia dan pemberian antibiotik. Faktor risiko lain seperti umur $<12$ bulan, pemberian obat antidiare, tidak mendapatkan ASI, pemberian susu formula, berat badan lahir rendah, serta adanya penyakit penyerta tidak dapat disimpulkan pengaruhnya terhadap berkembangnya diare akut menjadi diare persisten, sedangkan dilihat dari kekuatan masing-masing faktor risiko terhadap diare persisten ini berturut-turut, status gizi $<70 \%$, adanya anemia dan pemberian antibiotik dengan rasio odds dan IK berturut-turut: 10,974 (IK 95\% 3,442-34,814), 2,568 (IK 95\% 1,313-5,024), 1,984 (IK 95\% 0,021-3,854).

Dari tiga variabel yang bermakna pada analisis univariat, ternyata hanya 2 variabel yang bermakna pada uji multivariate regresion logistic yaitu status gizi < $70 \%$ dan adanya anemia dengan nilai $p$, rasio odds, dan IK 95\% berturu-turut: 0,001. 12,621 (K95\% 3,58044,501 ) dan 0,025. 2,374 ( IK 95\% 1,117-5,047).

\section{Diskusi}

Diare persisten penting untuk dipahami karena dapat menyebabkan gangguan pertumbuhan dan kehilangan berat badan 3 kali lebih tinggi, menyebabkan risiko kematian 7 kali lebih tinggi dibandingkan dengan diare akut serta merupakan 23\%-62\% kematian dari seluruh kematian karena diare atau pada penelitian lain bahkan menyebutkan $65 \% .^{1,4}$

Diare persisten dapat terjadi karena gabungan dari berbagai faktor yang saling berhubungan satu dengan

Tabel 2. Uji multivariat berdasarkan faktor-faktor risiko

\begin{tabular}{lccccc}
\hline Faktor-faktor Risiko & $\mathrm{B}$ & $\mathrm{SE}$ & $p$ & $\operatorname{Exp}(\mathrm{B})$ & $\mathrm{IK}(95 \%)$ \\
\hline Umur <12 bulan & 0,530 & 0,380 & 0,163 & 1,699 & $0,807-3,577$ \\
Malnutrisi & 2,535 & 0,643 & 0,001 & 12,621 & $3,580-44,501$ \\
Mendapat antibiotik & 0,764 & 0,406 & 0,060 & 2,148 & $0,970-4,758$ \\
Mendapat antidiare & $-0,044$ & 0,562 & 0,938 & 0,957 & $0,318-2,881$ \\
ASI (+) & 0,362 & 0,393 & 0,358 & 1,436 & $0,664-3,105$ \\
Susu formula (-) & 0,459 & 0,406 & 0,258 & 1,583 & $0,714-3,510$ \\
BBLR* & 0,069 & 0,624 & 0,912 & 1,071 & $0,316-3,636$ \\
Anemia & 0,865 & 0,385 & 0,025 & 2,374 & $1,117-5,047$ \\
Penyakit penyerta (+) & $-0,122$ & 0,746 & 0,870 & 0,885 & $0,205-3,822$ \\
\hline
\end{tabular}

${ }^{*} \mathrm{BBLR}=$ bayi berat lahir rendah 
lainnya. Meskipun demikian, apapun penyebabnya, titik tolak terjadinya diare persisten adalah adanya kerusakan mukosa usus yang berkelanjutan., $3,4,6,9$ Pemberian antibiotik, pada uji univariat secara statistik menunjukkan hasil yang bermakna $(p=0,042)$, hal ini dapat dijelaskan karena pada pemberian antibiotik pada diare akut yang tidak ada indikasi justru dapat menimbulkan efek samping yaitu terganggunya flora normal usus dan berpotensi dari diare akut berkembang menjadi diare persisten. Pada penelitian $\mathrm{Ngan}^{8}$ mendapatkan diare menjadi bertambah lama pada pemberian antibiotik dibandingkan dengan yang tidak mendapatkan antibiotik. $(p=0,01)$.

Faktor lain yang merupakan faktor risiko pada diare persisten, namun pada penelitian ini menunjukkan hasil yang tidak bermakna. Dapat dijelaskan bahwa penyebab diare persisten sangat kompleks dan merupakan gabungan banyak faktor yang saling berkaitan dan saling mempengaruhi. Data yang didapatkan dari catatan medik di jumpai data yang kurang lengkap, misalnya lama mendapatkan ASI atau susu formula sebelum diare, volume obat antidiare yang diberikan, derajat penyakit penyerta, umur dibatasi $<12$ bulan, dan berat badan lahir rendah < 2500 gram.

Pada laporan oleh Badruddin $\mathrm{dkk}^{9}$ dijumpai makanan pendamping termasuk pemberian susu formula dengan botol merupakan faktor risiko yang bermakna pada diare persisten. Penelitian Sazawal ${ }^{10}$ dan Ashraf $\mathrm{H}^{11}$ mendapatkan hasil penyakit penyerta merupakan faktor risiko pada diare persisten.

Anemia pada diare akut yang melanjut berkembang menjadi diare persisten menunjukkan hasil yang bermakna, $(p=0,005)$. Anemia secara umum dapat mempengaruhi pertumbuhan sel epitel dan proliferasi jaringan terutama pada jaringan gastrointestinalis dan pada gangguan gastrointestinalis absorpsi besi menjadi terganggu. ${ }^{12}$

Status gizi $<70 \%$ pada penelitian ini secara statistik sangat bermakna $p=0,001$ pada melanjutnya diare akut menjadi diare persisten. Pada malnutrisi atau status gizi $<70 \%$ ada beberapa mekanisme yang menyebabkan persistennya diare tersebut. Pada malnutrisi terjadi penurunan sintesis antibodi, kerusakan imunitas selular, penurunan motilitas saluran cerna dan penurunan kecepatan pertumbuhan sel epitel. Taniguchi ${ }^{13}$ dan Baqui ${ }^{14}$ mendapatkan malnutrisi dan gangguan imunitas selular merupakan faktor risiko utama pada diare persisten. Penelitian Lima ${ }^{15}$ mendapatkan faktor risiko yang meningkatkan diare persisten adalah malnutrisi dan infeksi cryptosporidium serta enteroadherent $E$. coli. Hal serupa juga dilaporkan Bhandari, ${ }^{6}$ dan Maung ${ }^{16}$ di mana malnutrisi atau status gizi $<70 \%$ meningkatkan risiko diare akut berkembang menjadi diare persisten.

Namun hal yang berbeda didapatkan pada penelitian Sodemann ${ }^{1}$ tidak dapat mengidentifikasi pengaruh signifikan pada diare akut yang berkembang menjadi diare persisten. Dengan melihat hasil penelitian ini, kita harus memberikan perhatian yang serius pada pasien diare akut dengan status gizi pasien $<70 \%$ dan diare akut pada anemia.

\section{Daftar Pustaka}

1. Sodemann M, Jakobsen MS, Melbak K, Martins C, Asby P. Episode-specific risk factors for progression of acute diarrhea to persistent diarrhea in West African children. Transactions of the royal society of tropical medicine and hygiene 1999;93,65-8.

2. Boediarso A. Persistent Diarrhea. Med J Indones.2002; 2 Supp1S25-31.

3. Yusuf S. Diare Persisten. Jurnal Gastrohepatologi Anak Indonesia 2007;1:6-23.

4. Firmansyah A. Pendekatan tata laksana diare persisten. Jurnal Gastrohepatologi Anak Indonesia 2007;1:99100.

5. Brunser O, Espinoza J, Araya M. Chronic diarrhea and malnutrition. Dalam: Gracey M, penyunting. Diarrhea. Boston: CRC Press;2000. h.163-84.

6. Bhandari N, Bhan MK, Sazawal S, Clemens JD, Bhatnagar S, Khoshoo V. Association of antecedent manultrition with persistent diarrhoe: a case-control study. Br Med J 1989;298:1284-7.

7. Pathela P, Hasan KZ, Ray E, Huq E, Siddique AK, Sack RB. Diarrheal illness in a cohort of children 0-2 years of age in rural Bangladesh: I Incidence and risk factor. Acta Paediatrica 2006;95:430-7.

8. Ngan PK, Khanh NG, Tuong CV, Quy PP, Anh DN, Thuy HT. Perisistent diarrhea in Vietnamese children: a preliminary report. Acta Paediatr 1992;81:124-6.

9. Badruddin SH, Islam A, Hendricks KM, Bhutta ZA, Shaikh S, Snyder JD. Diettary risk factors associated with acute and persistent diarrhea in children in Karachi, Pakistan. Am J Clin Nutr 1991;54:754-9.

10. Sazawal S, Bhan MK, Bhandari N, Clemens J, Bhatnagar $\mathrm{S}$. Evidence for recent diarrhoeal morbidity as a risk factor for persistent diarrhea: a case-control study. J.Epidemiol 
1991;20:540-5.

11. Asraf H, Ahmed S, Fuchs GJ, Mahalanabis D. Persistent diarrhoe: Associated infection and response to a low lactose diet. J Trop Pediatr 2002;48:142-8.

12. Gogle. Iron deficiency anemia, other causes, Treatment. Diunduh dari http://www.faqs.org/nutrition/A-Aplanemia. html. Diakses tanggal 6 September 2007.

13. Taniguchi K, Rikimaru T, Yartey JE, Akpedonu P, ArmarKlemesu MA, Nkrumah FK dkk. Immunological background in children with persistent diarrhea in Ghana. Pediatrics International 1999;41:162-7.

14. Baqui AH, Sack RB, Black RE, Chowdhury HR, yunus
M, Siddique AK. Cell-mediated immune deficiency and malnutrition are independent risk factors for persistent diarrhea in Bangladeshi children. Am J Clin Nutr 1993;58:543-8.

15. Lima AA, Fang G, Schorling JB, de Albuquerque L, McAuliffe JF, Mota S. Persistent diarrhea in northeast Brazil: etiologies and interactions with malnutrition. Acta Paediatr 1992;381:39-44.

16. Maung U K, Khin M, Wai NN, Hman NW, Myint TT, Butler T. Risk factors for the development of persistent diarrhea and malnutrition in Burmese children. International Journal of Epidemiology 1992;21:1021-9. 